Virtual Mentor. January 2004, Volume 6, Number 1.

doi: 10.1001/virtualmentor.2004.6.1.oped1-0401

Op-Ed

\title{
Activism? Yes! The AMA? Maybe Not
}

\section{Physician organizations have an ethical obligation to advocate for general improvement of public health, even if it is sometimes at the expense of interests of medical professionals.}

Howard Brody, MD, PhD

Physicians have a social responsibility to become actively involved in organizational efforts to improve the health and well-being of their patients and of the community. Ideally the physician would become involved in at least 2 sorts of efforts. One is the improvement of medical practice through raising standards, enhancing continuing education, and other efforts. The other is advocating for political changes that would improve health or access to health care for all. In some cases, membership in the same organization can meet both goals. For example, as a member of the American Academy of Family Physicians (AAFP) I can work to enhance the quality of my specialty and also advocate for the AAFP's plan for national health care reform. While I use the example of the AAFP, the obligation does not require that physicians join any particular organization, and I would argue specifically that it does not require membership in the American Medical Association (AMA).

Social activism of the highest caliber requires that the organization send a clear message. It is quite appropriate for a physicians' organization to advocate on behalf of the health of the public. It is also appropriate for a physician's organization to advocate on behalf of the interests of physicians themselves. After all, if not us, then who would? What is not appropriate is for the organization to do the second under the guise of the first. As the AMA rose to a position of almost unparalleled power during the first half of the 20th century - to the extent that it could defeat virtually any member of Congress who disagreed with its stance against "socialized medicine" in 1946-48-it often abused that power by claiming to defend the public's health when its real agenda was to defend physicians' incomes and privileges $[1,2]$. The AMA has tried in many ways to modernize and to occupy a new role in a world that has changed dramatically since the 1940s. Yet the old patterns of behavior are still in evidence often enough for many physicians to feel ethically compromised by AMA membership.

The usual counterargument is that if you wish to reform the AMA, you must join and try to change the organization from within. The difficulty in doing this, however, was revealed by the debate over physician-assisted suicide. The AMA has taken a very uncompromising position on this issue. When the Michigan State Medical Society adopted a moderate stance, for example, stating that physicians of conscience might disagree on this contentious issue much as they do on abortion, the AMA applied considerable pressure to get the Michigan House of Delegates to repudiate the state position and adopt the more conservative AMA position. A survey of physicians' attitudes revealed a singular difference between rank and file AMA members and the AMA leadership. The leaders were considerably more conservative politically than the general membership. Many more members than leaders of the AMA had at least some sympathy with the physician-assisted suicide option [3]. It does not appear, then, that the AMA consulted its membership before stating its uncompromising position on this issue. Consequently, it appears that change from within is not a viable option.

In other instances, the AMA did consult with its members but ironically to the detriment of its ethical stance on issues such as selling health-related products from the physician's office and treating members of one's family. In these cases the Council on Ethical and Judicial Affairs was reportedly prepared to offer guidelines that called the membership to a higher level of ethical behavior. The House of Delegates, it was reported, was offended by the idea that many 
practitioners' behaviors might be viewed as unethical. In this case the "good ol' boy" network presumably prevailed. The ethical stance eventually adopted was based on the lowest common denominator rather than aspiration toward something better.

One of the most telling indictments of the AMA's ethical stance on the health of the American public has been its record in health care reform debates. The prime example is the 1993 debate over Clinton administration's health reform proposal. Initially the AMA opposed many aspects of the Clinton plan but endorsed the basic idea of an employer mandate-that all employers should pay at least something toward health insurance for their employees. After extensive debate, the AMA House of Delegates backed off support for an employer mandate. The main reason, according to press accounts, had nothing to do with what was best for the health of the nation. Rather, it had to do with the fact that private medical practitioners are small businesspersons. One third of the AMA membership it was reported, do not provide health benefits for their own office employees and objected to a possible demand that they do so in the future [4]. That is, numerous members of the House of Delegates were willing to go on record as being opposed to adequate access to health care for their office staff rather than reduce their profits. Health reform proposals that have been offered by the AMA since the defeat of the Clinton plan all seem to have the same characteristics. Above all, these plans appear to protect physicians more than the public's health. They have tended to assure high reimbursement for physicians yet have been notably weak on features that would actually guarantee quality, affordable care for all Americans.

The task of improving the health of the public is too large to be handled satisfactorily by medical practitioners seeing patients in our offices one at a time. Without organized group efforts, we physicians will never be fully effective in addressing the entire range of health concerns. I would, however, hate to see the ethical obligation to devote a reasonable portion of one's busy schedule to these efforts become misconstrued as an ethical obligation To join any particular national organization-even the principal organization representing American physicians. While perhaps some day in the near future this organization will clean up its act and prove itself worthy of the allegiance of all thoughtful and conscientious American physicians, I believe it still has a long way to go.

\section{References}

1. Stevens R. American Medicine and the Public Interest. New Haven, CT: Yale University Press; 1971. Google Scholar

2. Starr P. The Social Transformation of American Medicine. New York: Basic Books; 1982. Google Scholar

3. Whitney SN, Brown BW Jr, Brody H, Alcser KH, Bachman JG, Greely HT. Views of United States physicians and members of the American Medical Association House of Delegates on physician-assisted suicide. J Gen Intern Med. 2001;16:290-296.

View Article PubMed Google Scholar

4. Weisskopf M, Priest D. AMA steps back from major part of Clinton health care plan. Washington Post. December 8, 1993:A3.

Howard Brody, MD, PhD, is a professor in the Department of Family Practice and Center for Ethics and Humanities in the Life Sciences at Michigan State University in East Lansing, MI. He is author of several books on medical ethics and other medical issues including The Healer's Power, Stories of Sickness, and a co-author of Cholera, Chloroform, and the Science of Medicine: A Life of John Snow.

The viewpoints expressed on this site are those of the authors and do not necessarily reflect the views and policies of the AMA.

(C) 2004 American Medical Association. All Rights Reserved. 